RESEARCH ARTICLE

\title{
Risk assessment of solar energy investments
}

\author{
E.C. Akçay* \\ Middle East Technical University, Civil Engineering Department, Ankara, Turkey
}

\begin{abstract}
Renewable energy sources have gained importance as the world's energy demand has increased over the years. In many countries, governments have started to give more importance to renewable energy sources in order to supply the growing energy demand. As a developing country, Turkey has also increased energy demand. New investments are needed in the renewable energy sector in order to satisfy this increasing demand. Solar energy has become one of the popular options among all renewable sources due to its widespread availability. Investments to produce solar energy can be feasible options for investors, but the risk factors stemming from the macro environment as well as project level risks should be identified. The objective of this study was to identify the risk factors and their impacts on the cash flow parameters of solar energy investments. To that end, an extensive literature survey is carried out relating to the risk factors of Public Private Partnership (PPP) projects, a survey questionnaire is applied to three different companies, and a Delphi method is used for the reduction process. The results are expected to guide the future solar energy investors in Turkey.
\end{abstract}

\section{Keywords}

Renewable energy; Investment; Solar; Risk factor; Project

Received: 12 December 2018; Accepted: 24 December 2018

ISSN: 2630-5771 (online) () 2018 Golden Light Publishing All rights reserved.

\section{Introduction}

Energy is an important factor for the economic and social development of countries. It is also indispensable factor for increasing the social welfare of a country. Energy demand has been increasing all over the world as a consequence of rapidly increasing industrialization and population growth [1]. According to the U.S. Energy Information Administration [2], the energy demand will increase significantly (28\% until 2040) for years to come (Fig. 1).

As a fast growing country, Turkey has also increased energy demand. It was announced by the Economist Intelligence Unit that Turkey's energy demand will have increased by an annual rate of
$5.6 \%$ in 2017. In the light of this information, it is clear that Turkey needs to find resources in order to supply the increasing energy demand. The energy sources can be categorized under two main headings as non-renewable and renewable. Nonrenewable energy sources include coal, natural gas, petroleum and nuclear energy, on the other hand, renewable energy sources include wind, sunlight, biological materials, geothermal heat and rain [3]. As Topal and Arslan [4] stated, Turkey is not a rich country in terms of non-renewable energy sources. Contrary to non-renewable energy sources, renewable energy sources are abundant, However, as Hargreaves and Zaccaria [5] mentioned the current level of their development and management

* Corresponding author

Email: emrecanerakcay@gmail.com 
is inadequate to meet the demand of the world's increasing population. The Turkish government leans towards renewable energy but does not have enough funds to invest in renewable energy power plants. Like other developing countries, the Turkish government uses public-private partnerships (PPPs) for constructing renewable energy power plants. Among all renewable energy alternatives, solar energy has become one of the popular renewable energy sources in Turkey due to its widespread availability. Turkey has a high potential for solar energy but this potential was not evaluated sufficiently until 2014. After 2014, with the growth of the economy, the installed solar power plant capacity in Turkey has been dramatically increased (shown in Fig. 2).
At the moment, the capacity of solar power plants is approximately 4726 Megawatt (MW) in Turkey. The total capacity for the installed solar power plants is expected to reach 10,000 MW by 2023. Therefore, solar power plants can be profitable investment alternatives for investors, however the risk assessment should be carefully carried out before making the investment. The objective of this study is to identify the risk factors, probabilities, and impacts on cash flow parameters to guide the future investors. As a result of this identification, a risk assessment table is constructed where one can find all risk factors, probabilities, and impacts for solar energy investments in Turkey.

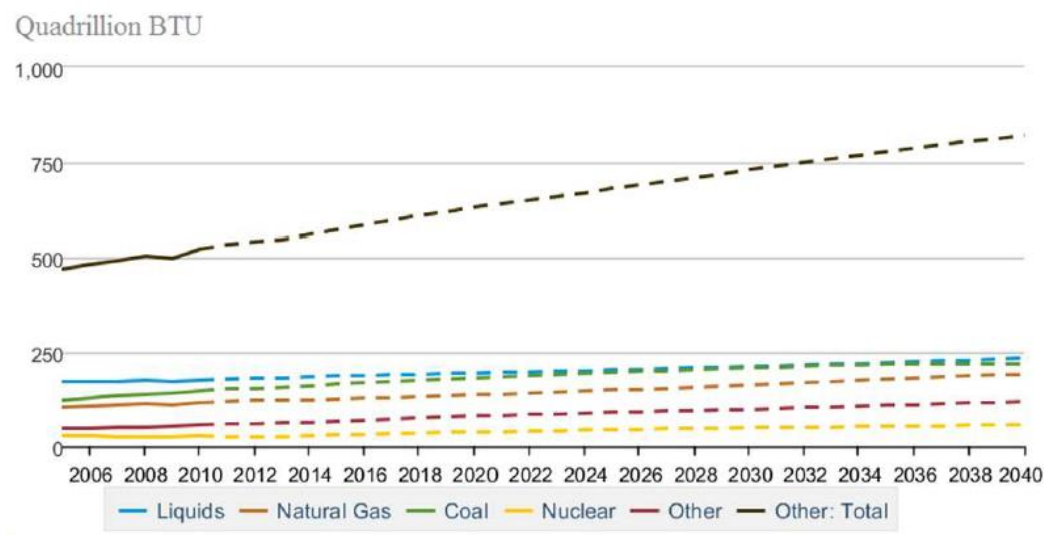

Fig 1. Projected Global Energy Consumption [2]

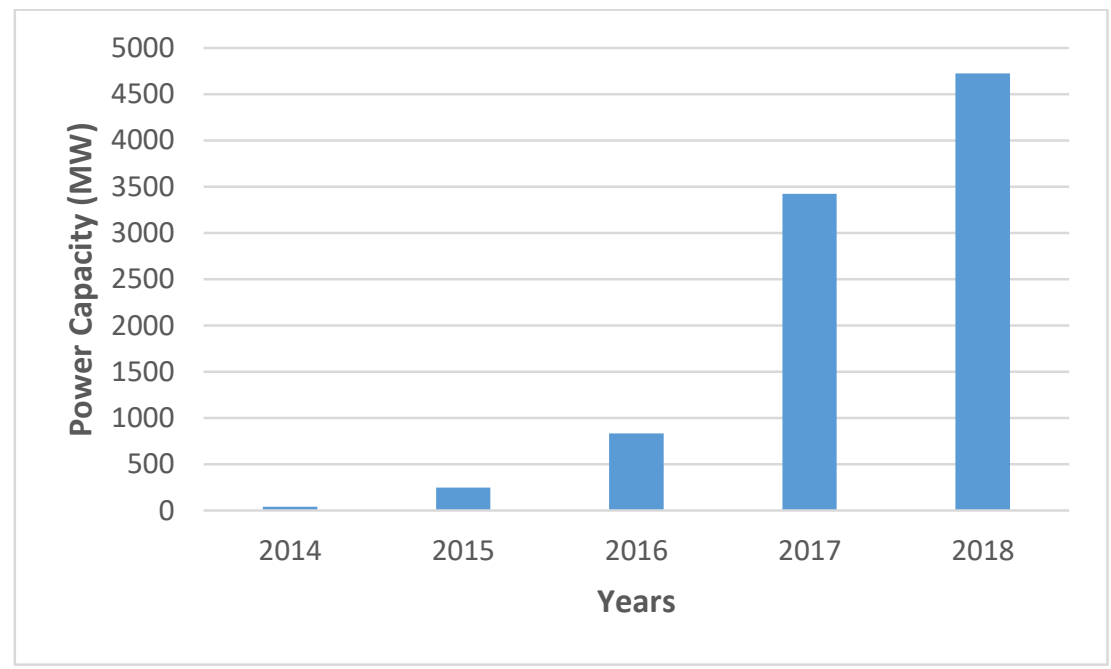

Fig 2. The Total Capacity for the Installed Solar Power Plants 


\section{Background research}

This research builds on and extends studies about implementation of renewable energy sources and risk identification in PPP projects.

Implementation of renewable energy sources have recently getting the attention of the researchers. Several research studies were performed to assess the potential of renewable energy sources. Zafar et al. [6] analyzed the different types of renewable energy sources in Pakistan. Mezher et al. [7] depicted opportunities for renewable energy investments in Abu Dhabi. Gómez-Navarro [8] assessed the barriers for renewable energy investments in Colombia. Furthermore, several research studies focused on environmental and social impacts of renewable energy sources [9-11]. For the choice of solar power as a renewable energy sources, studies have been conducted to evaluate its potential, challenges associated with its implementation, pricing, and policies adopted. Chang and Starcher [12] evaluated benefits and economic feasibility of solar energy investments in Texas. Keeley and Matsumoto [13] clarified the relative significance of the determinants in the location decisions of foreign solar energy investors. Totally, 18 determinants that are categorized into the macroeconomic environment, institutional environment, natural conditions, and renewable energy policy categories are used for the analysis. Other research studies focused on solar panel technology [14-17].

Several research studies were performed to identify the risk factors that affect different types of PPP projects in different countries [18-26]. For example, Al-Azemi et al. [25] identified the risk factors for PPP projects in Kuwait. Although there have been quite research studies related to renewable energy sources and solar power plants, and risk factors for PPP, there is not any specific study in the literature that guides to the investors in the sense of identification of risk factors for solar power plants in Turkey. Therefore, this study aims to guide the investors who interested in solar power plant investments in Turkey.

\section{Methodology of study}

The proposed methodology (Fig. 3) to identify the risk factors and impacts related to solar power investments is performed in three steps: (1) performing an extensive literature review, and (2) identifying of the cash flow parameters for solar power investments, and (3) identifying the impacts and probability of occurrence of the risk factors.

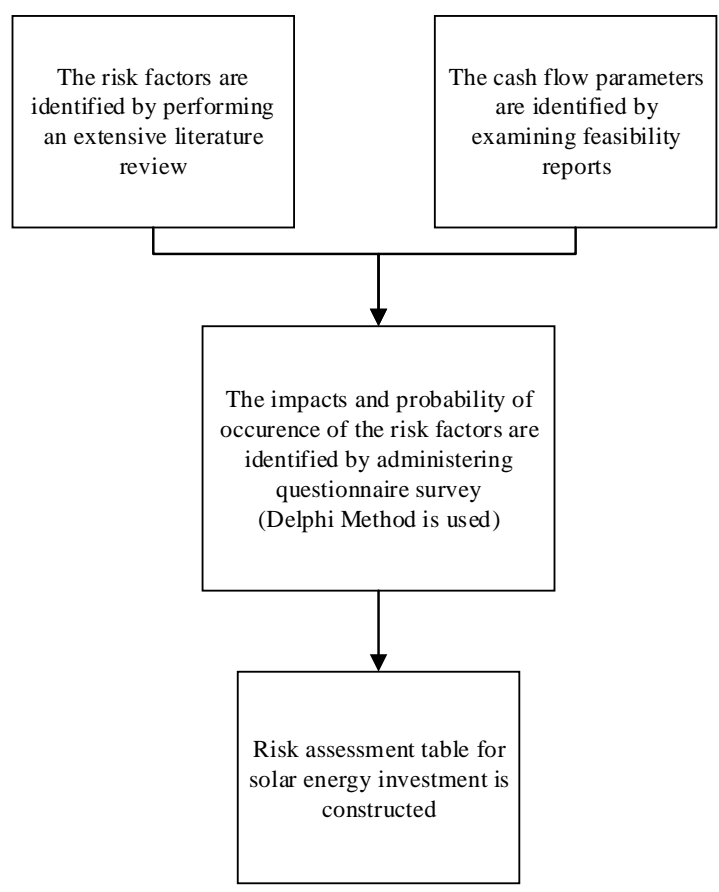

Fig 3. The flowchart of proposed methodology

\subsection{An extensive literature reviews}

The first step of the proposed methodology is to perform an extensive literature review. This process was performed by examining literature studies [1,18,19,21,23,27-31] prepared for PPP investments. Although there are many related publications in the literature, the selection process were performed according to the journal impact factor and citation records of the publication. According to these literature studies, 18 possible risk factors are identified. These risk factors are grouped as technical and external risk factors (Table 1). 
Table 1. Risk factors for solar energy investments

\begin{tabular}{l}
\multicolumn{1}{c}{ Risk Factors } \\
\hline \multicolumn{1}{c}{ External Risk Factors } \\
\hline Change in interest rates \\
Change in government \\
Change in law \\
Change in tax regulations \\
Change in energy market demand \\
Inflation rate volatility \\
Force majeure risk \\
Weather conditions \\
Local opposition \\
Delay in project approvals \\
Delay in expropriation \\
\hline Technical Risk Factors \\
\hline Delay of construction \\
Technical problems during construction \\
Organization risk \\
Change of scope \\
Geotechnical conditions \\
Accidents \\
Design problems
\end{tabular}

\subsection{Identification of the cash flow parameters of solar power investments}

The second step of the proposed methodology is to identify the cash flow parameters (Table 2) that affect solar power investments. This process was performed by examining more than 10 feasibility reports for solar power investments in Turkey. These reports were obtained from different investment companies.

The selection process were performed according to the size of the projects. In order to satisfy the project variation, the feasibility reports for small, medium and large scale projects were chosen. According to these feasibility reports, the profit of the project depends on income, cost of expropriation, operation cost, interest rate, construction cost, operation period and construction period.
Table 2. Cash flow parameters for solar energy investments

\section{Cash Flow Parameters}

Income

Cost of Expropriation

Operation Cost

Interest Rate

Construction Cost

Operation Period

Construction Period

\subsection{Identification of the impacts and probability of occurrence of the risk factors}

The third step of the proposed methodology involves identifying the impacts and probability of occurence of the risk factors. For this purpose, a questionnaire survey was administered to three different investment companies. All companies invest in the field of renewable energy production in Turkey. These companies are selected because they are international companies and invested different types of renewable power plants in different regions of Turkey. Company A constructed and is now operating three solar power plants with a total capacity of $30 \mathrm{MW}$, Company B constructed and is now operating six solar power plants with a total capacity of $42 \mathrm{MW}$, Company C constructed and is now operating four solar power plants with a total capacity of $88 \mathrm{MW}$. A total of 15 experts were chosen from these investment companies.

As can be seen in Table 3, all three companies are directly involved in construction and operation period for different types of renewable power plants, and each of them have experienced more than 5 years. The experiences and variety of companies helped in identifying the impact and probability of risk factors. The prepared questionnaire was applied to one executive manager and four project managers of each company. Before the questionnaire, participants were asked to evaluate the risk factors, and asked if they want to add new factors. After that process, the questionnaire was applied to a total of 15 participants (5 participants for each company). 
Table 3. Profile of the companies that participated in the study

\begin{tabular}{lcccc}
\hline & $\begin{array}{c}\text { Experience } \\
\text { (years) }\end{array}$ & $\begin{array}{c}\text { Number of solar } \\
\text { power plants } \\
\text { constructed and in } \\
\text { operation period }\end{array}$ & $\begin{array}{c}\text { Solar Energy } \\
\text { Production } \\
\text { Capacity (MW) }\end{array}$ & $\begin{array}{c}\text { Other types of renewable power plants } \\
\text { constructed and in operation period }\end{array}$ \\
\hline Company A & 8 & 3 & 30 & Hydro, Biomass \\
Company B & 15 & 6 & 42 & Wind, Hydro \\
Company C & 24 & 4 & 88 & Wind, Geothermal \\
\hline
\end{tabular}

Participants were asked to assess the probability of occurence and impact of each risk factor from zero to five, where "zero" shows risk factor has no probability and impact, "one" shows risk factor has very low probability and impact, "two" shows risk factor has low probability and impact, and "three" shows risk factor has medium probability and impact, "four" shows risk factor has high probability and impact "five" shows risk factor has very high probability and impact.

The Delphi Method was implemented to minimize the differences between participants. In this technique the questionnaire is answered by the experts in two or more rounds. After each round, the questionnaire that includes all the expert's answers are given to the experts and they are asked to revise their earlier answers in the light of the other experts' answers. By performing this process, the range of the answers are minimized in each round and also the degree of consensus for the results is increased in each round. After all rounds are completed, the mode of the answers are determined as a final result of the questionnaire.

\section{Results}

A risk assessment table was constructed in order to show the results of questionnaire. The probability of occurence and impact of risk factors are shown in this risk assessment table. In the table, first column shows the type of the risk factor, second column shows the name of each risk factor, and other columns show the probability of occurence and impact of risk factors on cash flow parameters. The first letter shows the probability of occurence of the risk factor $(\mathrm{V}=$ Very Low, $\mathrm{L}=$ Low, $\mathrm{M}=$
Medium, H= High, E= Very High), where the second letter shows the impact of the risk factor on the cash flow parameter $(\mathrm{V}=$ Very Low, L= Low, $\mathrm{M}=$ Medium, $\mathrm{H}=$ High, $\mathrm{E}=$ Very High). For example, the probability of occurence for "Organization Risk" is medium, whereas the impact of "Organization Risk"on "Income" parameter is low.

According to Table 4, the most influential risk factors on cash flow parameters are inflation rate volatility and change in interest rates. As Akcay et al. 2017 mentioned these two risk factors depend on the economic stability of the government. Also, it can be easily seen that inflation rate volatility, change in interest rates and delay in project approvals have the highest chance for probability of occurrence compared to the other risk factors.

\section{Conclusion}

In conclusion, this paper provides general information about energy demand and statistical information related to Turkey. The Turkish government's available and targeted installed capacity for solar energy power plants were stated. The cash flow parameters of solar energy investments were clarified. All technical and external risk factors were identified by performing an extensive literature review. The probability of occurrence of each risk factor and the impact of each risk factor on each cash flow parameter were identified. The presented risk assessment table in this research which shows probability of occurrence and impact of each risk factor can be a guide to the future solar energy investors in Turkey. 
Table 4. Risk assessment table for solar energy investments

\begin{tabular}{|c|c|c|c|c|c|c|c|c|}
\hline Type & $\begin{array}{ll} & \text { Cash Flow Parameters } \\
\text { Risk Factors } & \\
\end{array}$ & Income & $\begin{array}{l}\text { Interest } \\
\text { rate }\end{array}$ & $\begin{array}{l}\text { Construc. } \\
\text { period }\end{array}$ & $\begin{array}{l}\text { Operation } \\
\text { period }\end{array}$ & $\begin{array}{l}\text { Cost of } \\
\text { expropriation }\end{array}$ & $\begin{array}{l}\text { Operation } \\
\text { cost }\end{array}$ & $\begin{array}{l}\text { Construc. } \\
\text { cost }\end{array}$ \\
\hline \multirow{7}{*}{ 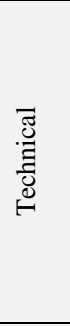 } & Delay of construction & {$[\mathrm{M}, \mathrm{V}]$} & {$[\mathrm{M}, \mathrm{V}]$} & [ M, E ] & [ M, E ] & {$[\mathrm{M}, \mathrm{V}]$} & {$[\mathrm{M}, \mathrm{V}]$} & [ M, E ] \\
\hline & Technical problems during construction & {$[\mathrm{H}, \mathrm{V}]$} & {$[\mathrm{H}, \mathrm{V}]$} & {$[\mathrm{H}, \mathrm{H}]$} & {$[\mathrm{H}, \mathrm{H}]$} & {$[\mathrm{H}, \mathrm{V}]$} & {$[\mathrm{H}, \mathrm{L}]$} & {$[\mathrm{H}, \mathrm{H}]$} \\
\hline & Organization risk & {$[\mathrm{M}, \mathrm{L}]$} & {$[\mathrm{M}, \mathrm{L}]$} & {$[\mathrm{M}, \mathrm{E}]$} & [ M, E ] & {$[\mathrm{M}, \mathrm{V}]$} & {$[\mathrm{M}, \mathrm{H}]$} & {$[\mathrm{M}, \mathrm{H}]$} \\
\hline & Change of scope & {$[\mathrm{L}, \mathrm{L}]$} & {$[\mathrm{L}, \mathrm{V}]$} & {$[\mathrm{L}, \mathrm{H}]$} & {$[\mathrm{L}, \mathrm{H}]$} & {$[\mathrm{L}, \mathrm{L}]$} & {$[\mathrm{L}, \mathrm{M}]$} & {$[\mathrm{L}, \mathrm{H}]$} \\
\hline & Geotechnical conditions & {$[\mathrm{M}, \mathrm{V}]$} & {$[\mathrm{M}, \mathrm{V}]$} & {$[\mathrm{M}, \mathrm{H}]$} & {$[\mathrm{M}, \mathrm{H}]$} & {$[\mathrm{M}, \mathrm{V}]$} & {$[\mathrm{M}, \mathrm{V}]$} & {$[\mathrm{M}, \mathrm{H}]$} \\
\hline & Accidents & {$[\mathrm{M}, \mathrm{L}]$} & {$[\mathrm{M}, \mathrm{V}]$} & {$[\mathrm{M}, \mathrm{M}]$} & {$[\mathrm{M}, \mathrm{M}]$} & {$[\mathrm{M}, \mathrm{L}]$} & {$[\mathrm{M}, \mathrm{M}]$} & {$[\mathrm{M}, \mathrm{H}]$} \\
\hline & Design problems & {$[\mathrm{H}, \mathrm{E}]$} & {$[\mathrm{H}, \mathrm{V}]$} & {$[\mathrm{H}, \mathrm{H}]$} & {$[\mathrm{H}, \mathrm{H}]$} & {$[\mathrm{H}, \mathrm{V}]$} & {$[\mathrm{H}, \mathrm{H}]$} & {$[\mathrm{H}, \mathrm{H}]$} \\
\hline \multirow{11}{*}{ 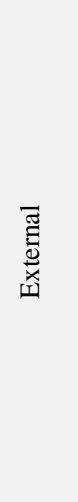 } & Change in interest rates & {$[\mathrm{E}, \mathrm{L}]$} & [E, E ] & {$[\mathrm{E}, \mathrm{L}]$} & {$[\mathrm{E}, \mathrm{L}]$} & {$[\mathrm{E}, \mathrm{V}]$} & {$[\mathrm{E}, \mathrm{L}]$} & {$[\mathrm{E}, \mathrm{M}]$} \\
\hline & Change in government & {$[\mathrm{M}, \mathrm{H}]$} & {$[\mathrm{M}, \mathrm{H}]$} & {$[\mathrm{M}, \mathrm{M}]$} & {$[\mathrm{M}, \mathrm{M}]$} & {$[\mathrm{M}, \mathrm{H}]$} & {$[\mathrm{M}, \mathrm{M}]$} & {$[\mathrm{M}, \mathrm{H}]$} \\
\hline & Change in law & {$[\mathrm{H}, \mathrm{E}]$} & {$[\mathrm{H}, \mathrm{L}]$} & {$[\mathrm{H}, \mathrm{M}]$} & {$[\mathrm{H}, \mathrm{M}]$} & {$[\mathrm{H}, \mathrm{H}]$} & {$[\mathrm{H}, \mathrm{L}]$} & {$[\mathrm{H}, \mathrm{L}]$} \\
\hline & Change in tax regulations & {$[\mathrm{H}, \mathrm{H}]$} & {$[\mathrm{H}, \mathrm{V}]$} & {$[\mathrm{H}, \mathrm{V}]$} & {$[\mathrm{H}, \mathrm{V}]$} & {$[\mathrm{H}, \mathrm{L}]$} & {$[\mathrm{H}, \mathrm{M}]$} & {$[\mathrm{H}, \mathrm{H}]$} \\
\hline & Change in energy market demand & {$[\mathrm{L}, \mathrm{E}]$} & {$[\mathrm{L}, \mathrm{V}]$} & {$[\mathrm{L}, \mathrm{V}]$} & {$[\mathrm{L}, \mathrm{V}]$} & {$[\mathrm{L}, \mathrm{L}]$} & {$[\mathrm{L}, \mathrm{L}]$} & {$[\mathrm{L}, \mathrm{V}]$} \\
\hline & Inflation rate volatility & {$[\mathrm{E}, \mathrm{M}]$} & {$[\mathrm{E}, \mathrm{E}]$} & {$[\mathrm{E}, \mathrm{M}]$} & {$[\mathrm{E}, \mathrm{M}]$} & {$[\mathrm{E}, \mathrm{L}]$} & {$[\mathrm{E}, \mathrm{H}]$} & {$[\mathrm{E}, \mathrm{H}]$} \\
\hline & Force majeure risk & {$[\mathrm{V}, \mathrm{L}]$} & {$[\mathrm{V}, \mathrm{L}]$} & {$[\mathrm{V}, \mathrm{H}]$} & {$[\mathrm{V}, \mathrm{H}]$} & {$[\mathrm{V}, \mathrm{V}]$} & {$[\mathrm{V}, \mathrm{M}]$} & {$[\mathrm{V}, \mathrm{H}]$} \\
\hline & Weather conditions & {$[\mathrm{H}, \mathrm{V}]$} & {$[\mathrm{H}, \mathrm{V}]$} & {$[\mathrm{H}, \mathrm{E}]$} & {$[\mathrm{H}, \mathrm{E}]$} & {$[\mathrm{H}, \mathrm{V}]$} & {$[\mathrm{H}, \mathrm{L}]$} & {$[\mathrm{H}, \mathrm{H}]$} \\
\hline & Local opposition & {$[\mathrm{L}, \mathrm{L}]$} & {$[\mathrm{L}, \mathrm{V}]$} & {$[\mathrm{L}, \mathrm{H}]$} & {$[\mathrm{L}, \mathrm{H}]$} & {$[\mathrm{L}, \mathrm{E}]$} & {$[\mathrm{L}, \mathrm{L}]$} & {$[\mathrm{L}, \mathrm{M}]$} \\
\hline & Delay in project approvals & {$[\mathrm{E}, \mathrm{V}]$} & {$[\mathrm{E}, \mathrm{V}]$} & {$[\mathrm{E}, \mathrm{E}]$} & {$[\mathrm{E}, \mathrm{E}]$} & {$[\mathrm{E}, \mathrm{V}]$} & {$[\mathrm{E}, \mathrm{L}]$} & {$[\mathrm{E}, \mathrm{E}]$} \\
\hline & Delay in expropriation & {$[\mathrm{H}, \mathrm{L}]$} & {$[\mathrm{H}, \mathrm{V}]$} & {$[\mathrm{H}, \mathrm{M}]$} & {$[\mathrm{H}, \mathrm{M}]$} & [ H, M ] & {$[\mathrm{H}, \mathrm{L}]$} & {$[\mathrm{H}, \mathrm{H}]$} \\
\hline
\end{tabular}

\section{References}

[1] Akcay, E. C., Dikmen, I., Birgonul, M. T., Arditi, D. Estimating the Profitability of Hydropower Investments with a Case Study from Turkey. Journal of Civil Engineering and Management 23(8)(2017) 1002-1012.

[2] EIA. Energy Information Administration. Energy Conference Presentations https://www.eia.gov/conference/2016/. Date of access: 02.06.2018 (2016)

[3] Ellabban, O., Abu-Rub, H., Blaabjerg, F. Renewable energy resources: Current status, future prospects and their enabling technology. Renewable and Sustainable Energy Reviews 39 (2014) 748- 764.

[4] Topal, M., Arslan, E.I. Biyokütle Enerjisi ve Türkiye. VII. Ulusal Temiz Enerji Sempozyumu, 2008 İstanbul, Turkey.

[5] Hargreaves, G., Zaccaria D. Better Management of Renewable Resources Can Avert a World Crisis. Journal of Irrigation and Drainage Engineering 133(3) (2007) 201-205.

[6] Zafar, U., Rashid, T., Khosa, A., Shahid K. M., Rashid, M. An overview of implemented renewable energy policy of Pakistan. Renewable and Sustainable Energy Reviews 82 (2017) 654665.

[7] Mezher, T., Goldsmith, D., Choucri, N. Renewable Energy in Abu Dhabi: Opportunities and Challenges. Journal of Energy Engineering 137(4) (2011) 169-176.

[8] Gómez-Navarro, T., Ribó-Pérez, D. Assessing the obstacles to the participation of renewable energy sources in the electricity market of Colombia. Renewable and Sustainable Energy Reviews 90 (2018) 131- 141.

[9] Akella, A. K., Saini, R. P., Sharma, M. P. Social, economical and environmental impacts of renewable energy systems. Renewable Energy 34 (2011) 390-396.

[10] Abbasi, S. A., Abbasi, N. The likely adverse environmental impacts of renewable energy sources. Applied Energy 65 (2000) 121-144.

[11] Sakellariou, N., Mulvaney, D. Engineers and the Renewable Energy Transition: Challenges and Opportunities. J. Prof. Issues Eng. Educ. Pract. 139(1) (2013) 12-18.

[12] Chang, B. Starcher, K. Evaluation of Wind and Solar Energy Investments in Texas. Renewable Energy 132 (2018) 1348-1359.

[13] Keeley A. R., Matsumoto K. Relative significance of determinants of foreign direct investment in 
wind and solar energy in developing countries AHP analysis. Energy Policy 123 (2018) 337-348.

[14] Kasaeian, A., Eshghi A. T., Sameti M. A review on the applications of nano fluids in solar energy systems. Renewable and Sustainable Energy Reviews 39 (2018) 748- 764.

[15] Lund, H. Large-Scale Integration of Optimal Combinations of PV, Wind and Wave Power into the Electricity Supply. Renewable Energy 31 (2006) $503-515$.

[16] Bull, S. R. Renewable Energy Today and Tomorrow. Proceedings of the IEE 89(8) (2001) $1216-1226$.

[17] Goswami, D.Y., VIjayaranghavan S., Lu S., Tamm G. New and Emerging Development in Solar Energy. Solar Energy 76 (2004) 33-43.

[18] Wang, S. Q., Tiong, R. L. K., Ting, S. K., Ashley, D. Evaluation and management of foreign exchange and revenue risks in China's BOT projects. Construction Management and Economics 18 (2000) 197-207.

[19] Mane, S., \& Pimplikar, S. S. Risk Assessment of BOT Projects. International Journal of Computational Engineering Research 3(8)(2013) 63-69.

[20] Chan, A.P.C., Yeung, J.F.Y., Yu, C.C.P., Wang, S. Q., Ke, Y. Empirical study of risk assessment and allocation of public-private partnership projects in China. Journal of Management in Engineering, 27(3) (2011), 136-148.

[21] Schaufelberger, J. E. Risk management on BuildOperate-Transfer Projects. Construction Research Congress, 2005.

[22] Shao, Y., Yuan, J., Li, Q. Identification of the Residual Value Risk Factors for Road PPP Projects in China: Questionnaire Survey and Analysis. Proceedings of the 20th International Symposium on Advancement of Construction Management and Real Estate, 2016, 379-389.

[23] Askar, M. M., Gab-Allah, A. A. Problems facing parties involved in build, operate and transport projects in Egypt. Journal of Management in Engineering 18(4) (2002) 173-178.

[24] [Ghorbani, A., Ravanshadnia, M., Nobakht, M. B. A survey of risks in public private partnership highway projects in Iran. ICCREM 2014@ sSmart Construction and Management in the Context of New Technology, 2014, 482-492.

[25] Al-Azemi, K. F., Bhamra R., Salman A. F. M. Risk Management Framework for Build, Operate and Transfer (BOT) Projects in Kuwait. Journal of Civil
Engineering and Management 20(3) (2014) 415433.

[26] Tang, L., Shen, G., Skitmore M., Wang H. Procurement-Related Critical Factors for Briefing in Public-Private Partnership Projects: Case of Hong Kong. Journal of Management in Engineering 31(6) (2015).

[27] Xu, Y., Hu, C., Chan, A. P. C. Risk factors for running Public Private Partnerships (PPP) - An Empirical. IEEE (2009).

[28] Jin, X.H., Zhang, G. Modelling optimal risk allocation in PPP projects using artificial neural networks. International Journal of Project Management 29(2011) 591-603.

[29] Ke, Y., Wang, S., Chan, A. P. C., Lam, P. T. I. Preferred Risk Allocation in China's Public Private Partnership (PPP) Projects. Journal of Project Management 28(2010) 482-492.

[30] Shen, L.Y., Platten, A., Deng, X. Role of public private partnership to manage risk in public sector project in Hong Kong. International Journal of Project Management 24 (2006) 587-594.

[31] Zhang, X. Paving the Way for Public-Private Partnerships in infrastructure development. Journal of Construction Engineering and Management 131(1) (2005) 71-80. 